\title{
IMIGRANTE JAPONÊS: COMPREENDENDO O PROCESSO DE SEPARAÇÃO
}

Francisco Hashimoto

O objetivo deste trabalho consiste em compreender as vivências dos imigrantes japoneses no processo de separação de sua terra natal e o encontro com as terras brasileiras. Busca recuperar as lembranças que foram retidas e confrontálas com a nova situação encontrada no Brasil. A partir desse confronto, procurouse compreender como ocorreu a acomodação e o convívio das imagens idealizadas trazidas do Japão com as que foram aqui construídas, para o desenvolvimento do vínculo com a nova terra.

A pesquisa fundamenta-se na psicanálise e o objeto de análise constitui-se de relatos de dez imigrantes japoneses que vieram para o Brasil no período de 1908 a 1941, o que demarca uma amostra de pessoas que chegaram a este país sem bens materiais, locais de trabalho e residência previamente acertados.

O trajeto da pesquisa é marcado pela exploração de um mundo desconhecido que procurou-se desvelá-lo, buscando encontrar o significado e compreensão do que ficou na mente dos imigrantes. Aquilo que as pessoas conseguiram narrar, por meio de uma coerência que era deles, apenas deles.

Buscando referências na literatura sobre esse processo vivido, encontrou-se as dificuldades econômicas do Japão e a prática isolacionista que manteve aquele país distanciado dos outros por muitos séculos. Nesse material é mostrado que o aumento populacional, causador da fome foi um dos aspectos que começou a incomodar o povo japonês. A miséria no campo chegou a um estágio insuportável levando a migração interna. 
A história mostra que apesar da resistência das pessoas partirem por uma reformulação no regime governamental, a mudança do sistema feudal para o capitalista foi inevitável com a Reforma Meiji. A resistência existia também em relação à emigração para o exterior, devido ao vínculo que esses indivíduos mantinham com o seu país de origem.

Mas a emigração não foi possível de ser evitada, pois a preocupação da nação em não perder seus membros levou o governo a autorizar uma emigração temporária. Por ser temporária, foi essa a mentalidade que se desenvolveu junto aos seus descendentes. Buscar recursos materiais no mundo exterior, mas sempre com a perspectiva de retorno.

Assim, começa a história dessas pessoas, foco de nosso trabalho, e que vieram para o Brasil, apesar da forte vinculação com seu país de origem, depois de vencerem muitas barreiras. Trouxeram para esse país o sentimento de fidelidade, de obrigação e dívida para com a sua nação, projetada na figura do Imperador. Esse sentimento pode ser representado pelo on, que faz parte da cultura e tradição desse povo e conseqüentemente de sua identidade.

Para o Brasil, receptor desse contingente imigratório, as condições eram oportunas para que esse processo se efetivasse, principalmente pelo favorecimento do seu crescimento econômico. Outros fatores contribuíram de forma significativa: a necessidade de mão-deobra para o café, a abolição da escravidão, a imigração subvencionada, o interesse comercial dos estrangeiros e o desenvolvimento dos meios de transportes.

$\mathrm{O}$ choque de culturas, a dificuldade da língua, a dificuldade de vinculação com a terra ou questões ligadas à socialização do imigrante japonês no Brasil são assuntos tratados fartamente pela literatura existente, da qual temos conhecimento. Este trabalho é uma tentativa de ampliar o horizonte sobre esse assunto, preocupando-se com as questões afetivas e possibilitando a reconstrução da história e do tempo em um outro país. É uma tentativa de resgatar e compreender a subjetividade desses imigrantes no processo de vinculação com a nova terra.

A análise dos dados coletados demonstra que a expectativa dos japoneses em conseguir as condições financeiras desejadas e retornar ao seu país de origem tornou-se inviável, pois a terra cheia de promessas não realizou os sonhos dos imigrantes.

A imagem do Brasil que era divulgada internacionalmente não era real. A propaganda veiculada mostrava uma fartura de alimentos que era enganosa. Enfim, o sentimento de desamparo aliado aos fatores externos, como por exemplo, a resistência dos aqui radicados, mais a falta de perspectivas de colher os frutos desejados, provocaram o sentimento de perda e de vazio.

A perda do espaço vital provocou a dor da separação, oriunda da desorganização psíquica, vivenciada pela separação dos familiares de seu país. A ruptura de uma cultura 
milenar integrada ao indivíduo e a tentativa de adaptação a uma nova situação foi dificultada pelo processo desidentificatório vivido pelos imigrantes em um novo país.

$\mathrm{Na}$ trajetória desses imigrantes ocorreram duas formas de reação frente ao desconhecido: a vivência do luto, recurso utilizado pelo ego para defender-se do sentimento de vazio e a outra de melancolia, em que os mecanismos não são possíveis de serem acionados, provocando a morte psíquica. De qualquer forma, o elaborar a perda significou superar uma situação semelhante à da morte, que pode ser tanto do indivíduo como do outro - o país que vive dentro dele.

A ausência do objeto amado que é ao mesmo tempo uma fonte de identificação, produz no indivíduo o mecanismo de luta para se defender do vazio provocado por essa ausência. A sua luta tem como finalidade a desidentificação com o objeto para que a sua imagem deixe de ser focalizada com sofrimento. A elaboração deste tipo de luto significa um esforço sobre a separação e, durante esse momento, é freqüente o surgimento de fenômenos agressivos como um movimento desidentificatório deste objeto de amor ou desejo.

E através da agressividade dirigida ao objeto amado que se conseguem forças para desvalorizá-lo, porque ele está ausente. Essa desvalorização, através do levantamento dos aspectos negativos do ausente, possibilita ao indivíduo uma transformação do amor em ódio e conseqüente afastamento do mesmo. Esse afastamento como facilitador da desidentificação é, no entanto, o mecanismo pelo qual se consegue furtivamente o seu culto sem qualquer sofrimento. Esta é uma maneira segura encontrada para tornar a separação definitiva e, ao mesmo tempo, aceitável pelo indivíduo.

Decorrente e paralelamente a esse processo elaborativo ocorrem outros recursos protetores que são ativados para suportar a separação. Caminhando junto com os aspectos agressivos acontece, também, um movimento de revalorização do indivíduo. A indiferença e a tentativa de fugir da situação de conflito são recursos utilizados pelos imigrantes para finalizarem o objetivo buscado, a preservação do ausente eternizado e purificado de qualquer contaminação, mas que está distante e sentido como inatingível; é a imagem ideal mitificada. Por meio deste processo de afastamento, que o objeto ausente "será colocado na eternidade imóvel e rigida, onde não envelhecerá, não será indiferente nem infiel" (CARUSO, 1986, p.58). Esse corte temporal é possível e necessário porque o desejo é atemporal e não está submetido às regras da realidade. $O$ desejo sequer se confronta com a questão da temporalidade.

Para superar a separação um mecanismo de defesa da preservação do objeto é produzido na consciência, o qual fica retido, e geralmente é reforçado pelas ações das lembranças e dos fantasmas conscientes que estão ligados à perda. Todo trauma relacionado com perda do objeto amado está vinculado à castração, que é a inibição, sintoma da angústia. 
Os mecanismos de defesa que aparecem no processo de separação enfocam principalmente os problemas que ficam reprimidos na consciência das pessoas que sofrem da perda, "é a vivência da morte em minha consciência, graças à separação; complementar a esse, existe um outro problema que é narcisisticamente mais doloroso para quem sofre: a vivência de minha morte na consciência do outro" (CARUSO, 1986, p.26).

Como a separação provoca a morte do outro na consciência, ocorre o desespero pela perda do objeto amado. Logo, esta experiência acarreta uma catástrofe do ego, devido a perda do elemento de identificação. Uma forma utilizada pelo indivíduo para defender-se dessa ausência é a desvalorização do objeto ausente. Mesmo quando a pessoa percebia os aspectos negativos, existia uma forte tendência para ele ser o ideal do ego. A agressividade é um comportamento que surge como defesa do eu em função da perda do objeto amado. No processo de separação é necessário desvalorizar o outro para que o eu possa continuar sobrevivendo.

Outro mecanismo de defesa no período de separação é a indiferença, pois ela provoca a repressão e a rejeição do processo pela consciência. "Os fatores atuantes dentro do estou pouco me importando são sobretudo os seguintes: diminuição do ideal de ego, enfraquecimento do ego graças à desidentificação e proporcional aumento do narcisismo" (CARUSO, 1986, p.27). O ego e o superego (mecanismo de censura) se mantém num processo defensivo, de tal forma que o sentimento de 'estou pouco me importando' não apresenta força suficiente para superar o desespero. Este tipo de compromisso é acionado visando à conservação do ideal de ego.

Uma alternativa aparente de fuga é a busca do prazer, impulsionado geralmente pelo desejo. Ocorrem várias formas de fuga, como a busca de novos objetos que causam o prazer e a substituição de um pelo outro. $O$ eu que neste momento passa por um grande sofrimento necessita de consolo e as experiências passadas mostram que ele poder ser obtido por meio do prazer. Entretanto, nem sempre esse tipo de comportamento supera o sofrimento da perda do objeto desejado.

É importante ressaltar que esses comportamentos não se apresentam em ordem cronológica. Muitas vezes eles atuam entrelaçados e podem até se chocarem entre si, provocando comportamentos ambivalentes.

O objetivo final é a ideologização, que significa "em última análise, a afirmação de certa rebelião e com isso constituirá uma vitória parcial sobre a morte sofrida. É mais provável, portanto, que a ideologização se cristalize num não do que num sim, diante da separação" (CARUSO, 1986, p.28).

O processo de separação provoca a dor, o sofrimento. E esse sofrimento emerge nos recortes efetuados pelas histórias contadas pelos imigrantes. Tais recortes aparecem carregados de sentimento, de sofrimentos, mas também de alegrias e somente emergem 
porque as elaborações sobre os fatos ou fenômenos ocorreram. O trabalho psíquico só transparece a partir do que é lembrado, no colorido das imagens descritas que se produzem no distanciamento do próprio fato.

A resistência em amar o novo, devido a sua vinculação afetiva com a terra natal, levou o imigrante a efetuar um corte na passagem do tempo. Houve o corte temporal, para preservar a imagem do Japão, que veio inserida nos seus psiquismos. O tempo mítico permeou e dificultou todo o processo elaborativo de vinculação com a nova terra. $O$ mecanismo de negação da existência de outro atuou como forma de cultuar dentro deles a imagem do país e do desejo de retorno.

O espaço físico também não facilitou a percepção da passagem da vida. A ligação dos imigrantes japoneses com a natureza e o ato de viver as quatro estações do ano eram praticamente inviáveis naquela situação. A perda de referência levara à sensação de vazio e de estar solto num espaço e tempo desconhecidos.

A crise que desponta com a quebra forçada do vínculo com a terra natal provoca alterações no psiquismo do grupo familiar. Ao emigrar, eles tiveram que se reorganizar, pois a relação de familiaridade do imigrante com o espaço, com o habitat coletivo, onde os limites eram claros e contornados pelo mar, foram rompidos. Os espaços não eram somente descontínuos, mas sem contornos, sem limites, o que deixou o imigrante solto, não the permitindo localizar-se. A desorganização da representação do contorno espacial de sua terra desorganizou também o contorno espacial psíquico de cada pessoa, quebrando parte de sua identidade.

Além disso, o espaço aqui no Brasil é percebido e sentido de uma forma totalmente diferente: o local é extremamente agressivo e essa agressão é percebida de modo sensível porque o ego está fragilizado e o indivíduo, conseqüentemente, sente-se diminuído em sua auto-estima.

A diminuição da auto-estima provoca a agressividade e também o mecanismo de defesa ambivalente, de amor e ódio. A manifestação do desejo de ser amado não é atingida devido à ausência do ideal corporificada no indivíduo, resultando em uma espécie de amor sem conteúdo e também de um desespero sem conteúdo.

Era difícil o encontro com o novo. O espaço era hostil, as pessoas dificultavam a possibilidade de desenvolvimento de vínculos e, ao mesmo tempo, a resposta do imigrante por temor ou por sentir-se fragilizado era também de rejeição. Rejeita-se a quem é rejeitador. Ou foi o inverso que ocorreu? Ou o rejeitador, por sentir-se rejeitado nas origens, desencadeia a rejeição?

A desvalorização do ausente, que significa a negação dos aspectos positivos da terra natal, enquanto busca seu próprio caminho, é dificultada pela rejeição da terra presente. Apesar 
da única tentativa de solução do impasse ser a desvalorização, mesmo que agressiva, torna-se dificil a passagem para a idealização do ausente. É a vivência da perda, por meio do desgaste da imagem ideal, o mecanismo utilizado para possibilitar o engrandecimento desse ideal perdido, num processo de reparação e de projeção para o passado. Essa idealização de volta ao retorno ao amor antigo transparece também na dificuldade de fixar raízes na nova terra.

A resistência de fixar-se num lugar próprio e de referência poderia significar para o imigrante a impossibilidade de retorno, isto é, ficar para sempre no Brasil. É uma tentativa de defesa do ego para a não desvinculação com o objeto amado.

A dificuldade de distanciar-se da terra natal provoca um conflito com a realidade. Desde o momento da decisão de partir, já se instaura a negação do tempo em relação à vida em um outro país. Viver o tempo na presença do objeto amado é diferente de vivê-lo na ausência. Conseqüentemente, o viver um tempo vivo é diferente de um tempo morto.

A dificil trajetória dessas pessoas no processo de separação fez com que elas se utilizassem de todos os recursos psíquicos possíveis para proporcionar o fortalecimento do ego. $\mathrm{O}$ viver a ambivalência entre a lembrança idealizada e o frágil compromisso com 0 novo espaço era um conflito muito presente que necessitava de uma solução adequada. Mas, esse sentimento já era um indício de mudança.

Um novo encontro, depois de algum tempo de separação, possibilita ao indivíduo, perceber a discrepância entre a imagem ideal mitificada e a imagem real encontrada. Essa desilusão pode ser projetada para o seu país de origem, como uma descarga. Desta forma, podemos entender que o processo de luto se concretiza com o processo de diferenciação, na medida em que o indivíduo começa a perceber o novo e separar-se do outro. Essa separação não implica no esquecimento total, pois tal condição significaria a morte do ego.

$\mathrm{Na}$ separação, a pessoa deve desligar-se da imagem idealizada do ausente e procurar substituí-la por outros ideais. Além disso, precisa continuar desenvolvendo as suas atividades cotidianas para possibilitar a continuidade do ego. A separação consiste portanto, na tentativa de vencer os sentimentos de ambivalência entre a lembrança idealizada e o frágil compromisso com o objeto atual. A forma adequada de solucionar os conflitos é lançar mão das defesas. São esses mecanismos que vão possibilitar o desenvolvimento e adaptação à situação nova no Brasil. A vida das pessoas é cercada de sentimentos e desejos ambivalentes: amor e ódio, querer e não querer, gostar ou rejeitar e a função dos mecanismos de defesa é controlar essa ambivalência.

Passados os momentos de angústia e desespero, o fato de dedicar-se ao trabalho e ser reconhecido pelo empenho tornou-se uma das formas de sentir-se aceito social e internamente. Foi esse o objeto, por meio do qual o ego pôde adquirir condições de reorganizar-se e possibilitar a vinculação com outras pessoas, vislumbrando os aspectos positivos da nova terra. 
Para sobreviver à separação, a pessoa precisa ter esperança. $O$ ego, por meio dos mecanismos defensivos, possibilita a absorção da perda, recuperando-se dos ataques sofridos, num processo de vivenciar a dor. $\mathrm{Na}$ fase de ideologização que provoca a falta de crítica, o indivíduo acaba por das outra interpretação aos poderes que colocou para si, denominando-os de poderes da vida.

Constatou-se nos relatos que o fator afetivo, pouco explorado na literatura, influenciou decisivamente na vida das pessoas, como um aspecto facilitador do viver o presente, com base no passado e possibilitando projeções para o futuro. Esse processo foi a base da temporalidade subjetiva dos imigrantes. E é somente quando o indivíduo consegue integrar esses três tempos em seu psiquismo que são criadas condições e motivações para viver e renascer.

O ego fortalecidojá pode presenciar e sentir a passagem da vida, e poder até estabelecer relações com as estações do ano, como sentir que a primavera renascia em seu mundo. A imagem do Japão ficou idealizada e isso significou a possibilidade de amar o Brasil. Nesse processo separatório, não se pode afirmar que os imigrantes venceram a luta pela vida, mas significou que existiu a possibilidade de vida. Significou mais, que eles lutaram, trabalharam e também viveram, como o tempo que se renova a cada estação do ano.

Bibliografia

ALLEN, G.C. A economia japonesa. Rio de Janeiro: Zahar, 1983.

ANDO, Z.; WAKISSAKA, K. Sinópse da História Japonesa no Brasil. In: $\mathbf{O}$ japonês em São Paulo e no Brasil. São Paulo: Centro de Estudos Nipo Brasileiros, 1971.

ANZIEU, D. Os métodos projetivos. Rio de Janeiro: Campus, 1978.

BENEDICT, R. O crisântemo e a espada. São Paulo: Perspectiva, 1972.

BEZERRA JR, B. Subjetividade moderna e o campo da psicanálise. In: BIRMAN, J. (org.)

Freud cinquenta anos. Rio de Janeiro: Relume Dumará, 1989.

BLEGER, J. Temas em psicologia: entrevistas e grupos. São Paulo: Martins Fontes, 1989.

BOSI, E. Memória e sociedade: lembranças de velhos. São Paulo: T. a Queiroz, 1979.

CARUSO, I. A separação dos amantes. São Paulo: Diadorim: Cortez, 1986.

EIGUER, A . Um divã para a familia. Porto Alegre: Artes Médicas, 1989.

FERNANDES, H. R. Tempo e desejo: sociologia e psicanálise. São Paulo: Brasiliense, 1989.

FIGUEIRA, S. A . Nos bastidores da psicanálise. Rio de Janeiro: Imago, 1991. 
FREIRE, J. C. Psicanálise e contexto cultural. Rio de Janeiro: Campus, 1989.

HANDA, T. O imigrante japonês: a história de sua vida no Brasil. São Paulo: T. A Queiroz, 1987.

HASHIMOTO, F.; TANNO, J. L.; OKAMOTO, M. Cem anos de imigração japonesa no Brasil. São Paulo: Ed. Unesp, 2008. (Fapesp)

KRISTEVA, J. Sol negro- depressão e melancolia. Rio de Janeiro: Rocco, 1989.

MOREIRA, A. C. Clínica da melancolia. São Paulo: Escuta/Edufpa, 2002.

NOGUEIRA. A R. Imigração japonesa para a lavoura cafeeira paulista (1908-1922). São Paulo: IEB-USP, 1973.

PERES, U. T. Melancolia. São Paulo: Escuta, 1996.

ROHLEN, T. P. The promisse of adulthood in japonese spiritualim. New York: W Norton Company, 1978.

VIEIRA, F. I. S. O japonês na frente de expansão paulista. São Paulo: Pioneira, 1973. 